\title{
Obtaining the partially acidulated phosphate rocks by means of intermediate-grade phosphate and diluted phosphoric acid: Influence of some parameters
}

\author{
Abbes Mizane ${ }^{1 *}$, Ahmed Boumerah ${ }^{2}$, Noureddine Dadda ${ }^{2}$, Rabah Rehamnia ${ }^{2}$, Salah Belhait ${ }^{2}$ \\ ${ }^{1}$ University Badji Mokhtar, Laboratory of Water Treatment and Recycling of Industrial Waste, Department of Chemistry, \\ BP12, 23000, Annaba, Algeria \\ ${ }^{2}$ University Badji Mokhtar, Department of Chemistry, Annaba, Algeria \\ "Corresponding author: e-mail: abbes.mizane@univ-annaba.dz
}

\begin{abstract}
In this work, some parameters during the partial acidulation by phosphoric acid of phosphate 53.75\% BPL (bone phosphate of lime) having different particle sizes are determined. $\mathrm{P}_{2} \mathrm{O}_{5}$ recovery is obtained by performing a series of reactions using phosphoric acid diluted from 10 to $40 \mathrm{wt} . \%$ and with reaction times ranging from 10 to 50 minutes. The best conversion rates are obtained with the following reaction parameters: phosphates size: 88-177 $\mu \mathrm{m}$, reaction time: 50 minutes and phosphoric acid concentration: $40 \mathrm{wt} . \%$. In the second part, the water-soluble $\mathrm{P}_{2} \mathrm{O}_{5}$ of PAPRs (Partially Acidulated Phosphate Rocks) obtained with phosphoric acid 30\% and $40 \mathrm{wt} . \%$ is measured. The results of experiments showed that the water-soluble $\mathrm{P}_{2} \mathrm{O}_{5}$ has reached $15.2 \%$ for PAPRs obtained by reacting phosphate $88 \mu \mathrm{m}$ with phosphoric acid $40 \mathrm{wt} \%$.
\end{abstract}

Keywords: PAPRs, phosphate rocks, phosphoric acid, water-soluble $\mathrm{P}_{2} \mathrm{O}_{5}$.

\section{INTRODUCTION}

Phosphate rocks (PRs) from different sources are expected to behave differently in acidulation process because the composition of these rocks varies from one deposit to another ${ }^{1}$. Therefore, PRs contain one or more phosphate minerals suitable for commercial use, such as fluorapatite $\left.3 \mathrm{Ca}_{3}\left(\mathrm{PO}_{4}\right)_{2} \cdot \mathrm{CaF}_{2}\right)$. Chemistry of acidulation of apatite crystal structure is complicated. It is highly dependent on competing or synergistic factors specific to the type of phosphate rock mineral, such as porosity, surface area and impurities content, especially in the form of metal oxides of the general formula $\mathrm{R}_{2} \mathrm{O}_{3}{ }^{2}$. According IAEA $^{3}$ (International Atomic Energy Agency), the mineralogy of phosphorus rich rocks is complex and there are more than 200 known phosphate minerals. The grade of raw phosphate depends on the total phosphor content, type of impurities and amount of impurities. Total phosphor is expressed as ${ }^{4}$ :

Phosphorus pentoxide $\mathrm{P}_{2} \mathrm{O}_{5}$;

Calcium phosphate $\mathrm{Ca}_{3}\left(\mathrm{PO}_{4}\right)_{2}$ (BPL), where:

$\% \mathrm{P}_{2} \mathrm{O}_{5} \times 2.1853=\% \mathrm{BPL}\left(\mathrm{BPL} \times 0.4576=\% \mathrm{P}_{2} \mathrm{O}_{5}\right)$

Phosphate ores are divided into three groups according to their $\mathrm{P}_{2} \mathrm{O}_{5}$ content: low-grade ores $\left(12-16 \% \mathrm{P}_{2} \mathrm{O}_{5}\right)$, intermediate-grade ores (17-25\% $\left.\mathrm{P}_{2} \mathrm{O}_{5}\right)$, and high-grade ores $\left(26-35 \% \quad \mathrm{P}_{2} \mathrm{O}_{5}\right)$. Deposits that could be mined and processed economically to give about $28-38 \% \mathrm{P}_{2} \mathrm{O}_{5}$ are considered commercial phosphate deposits ${ }^{5}$. Manufacturers of phosphoric acid and phosphorus fertilizers normally require a minimum content of $28 \% \mathrm{P}_{2} \mathrm{O}_{5}$, and most marketed grades of phosphate rocks contain more than $30 \%$ of $\mathrm{P}_{2} \mathrm{O}_{5}(65 \% \mathrm{BPL})$. To meet this requirement, most phosphate ores undergo beneficiation by washing and screening, de-liming, magnetic separation and flotation ${ }^{6}$.

Acidulation of phosphate rocks with either sulphuric or phosphoric acids produces the phosphate components monocalcium phosphate (MCP), small amounts of dicalcium phosphate (DCP) and (omitting iron and aluminium species) quantities of residual apatite depending on the degrees of acidulation ${ }^{7}$. The reactions between PRs and these acids can be expressed using the following equations:

$2 \mathrm{Ca}_{5}\left(\mathrm{PO}_{4}\right)_{3} \mathrm{~F}+7 \mathrm{H}_{2} \mathrm{SO}_{4}+3 \mathrm{H}_{2} \mathrm{O} \rightarrow 3 \mathrm{Ca}\left(\mathrm{H}_{2} \mathrm{PO}_{4}\right)_{2}$.

$\cdot \mathrm{H}_{2} \mathrm{O}+7 \mathrm{CaSO}_{4}+2 \mathrm{HF}$

$\mathrm{Ca}_{5}\left(\mathrm{PO}_{4}\right)_{3} \mathrm{~F}+7 \mathrm{H}_{3} \mathrm{PO}_{4}+5 \mathrm{H}_{2} \mathrm{O} \rightarrow 5 \mathrm{Ca}\left(\mathrm{H}_{2} \mathrm{PO}_{4}\right)_{2}$

$\mathrm{H}_{2} \mathrm{O}+\mathrm{HF}$

PAPRs are generally prepared by reacting PRs with a less than the stoichiometric quantity of $\mathrm{H}_{2} \mathrm{SO}_{4}$ or $\mathrm{H}_{3} \mathrm{PO}_{4}$ required for preparing fully acidulated phosphate fertilizers such as single superphosphate (SSP) (Reaction 1) or triple superphosphate (TSP) (Reaction 2). The PAPRs contains part of its phosphorus in a water-soluble form $\mathrm{Ca}\left(\mathrm{H}_{2} \mathrm{PO}_{4}\right)_{2}$ and the rest mainly as unreacted apatite (residual PRs). Processes of PRs dissolution can be summarized as follows':

$\mathrm{Ca}_{10}\left(\mathrm{PO}_{4}\right)_{6} \mathrm{~F}_{2}+\mathrm{y}(6-\mathrm{x}) \mathrm{H}_{2} \mathrm{SO}_{4}+2 \mathrm{xyH}_{3} \mathrm{PO}_{4}+\mathrm{H}_{2} \mathrm{O} \rightarrow$

$\mathrm{y}(6-\mathrm{x}) \mathrm{CaSO}_{4}+(3+\mathrm{x}) \mathrm{yCa}\left(\mathrm{H}_{2} \mathrm{PO}_{4}\right)_{2} \cdot \mathrm{H}_{2} \mathrm{O}+$

$+(1-\mathrm{y}) \mathrm{Ca}_{10}\left(\mathrm{PO}_{4}\right)_{6} \mathrm{~F}_{2}+\mathrm{yCaF}_{2}$

Accordance with the equation (3):

- SSP is obtained when $\mathrm{y}=1$ and $\mathrm{x}=0$;

- TSP is obtained when $\mathrm{y}=1$ and $\mathrm{x}=6$;

- PAPRs is obtained when $0<\mathrm{y} \leq 0.75$.

In practice, the degree of PRs acidulation ranges from $20 \%$ to $50 \%$. Compared to the SSP and TSP, several studies ${ }^{10-13}$ have shown that the PAPRs may be a mean to improve agricultural efficiency at lower cost. In addition, PAPRs have the advantage of being often more concentrated than SSP. Despite little information is available in literature on $\mathrm{Cd}$ uptake by crops from either phosphate rock or partially acidulated, PAPRs may limit the absorption of this hazardous meta ${ }^{14}$. The solubility characteristics of the directly acidulated PAPRs are affected by the type, composition and concentration of the acid used for acidulation, degree of acidulation, nature and fineness of PRs, without forgetting the method of manufacture ${ }^{15,16}$. According to IFDC ${ }^{17}$, PAPRs are less expensive and cheaper than fully acidulated 
fertilizers because less acid and energy is required per unit of phosphorus in the product.

From the process point of view, it is possible to produce PAPRs commercially in several ways along the same lines as SSP and TSP. The preferred process should be one that gives the highest possible return on investment. Indeed, in the phosphate fertilizer NPK complex, it is possible to extract the diluted phosphoric acid to the phosphoric acid plant to produce PAPRs. With this aim in mind, the following factors should be taken into account: the quality of the PRs, process simplicity and his integration with existing facilities and the availability of other raw materials and services. But in all cases, the quality of the PRs remains the principal factor in deciding which process to use ${ }^{\mathbf{1 8 - 2 0}}$.

The phosphates of the area of Djebel Onk, located in the Southeast of Algeria, are part of a succession of sedimentary strata formed at the end of the Cretaceous-Eocene era ${ }^{21}$. phosphate rock, used in the experiments, is a fluorapatite and is characterized by a granular appearance; it has a high substitution of $\mathrm{CO}_{3}\left(\mathrm{CaO} / \mathrm{P}_{2} \mathrm{O}_{5}\right.$ $=1.75$ to 1.90 ) and generally is low in silica and in iron $^{22}$. From the literature and research we carried out on Djebel Onk phosphates, it can be concluded that only few investigations and studies were conducted on these phosphates despite their high quality $\left(24-28 \% \mathrm{P}_{2} \mathrm{O}_{5}\right)$ and important reserves (about 2 billions of tons) ${ }^{\mathbf{2 3}}$.

The main reason for choosing this subject is to valorize Djebel Onk phosphate ore $(53.75 \%$ BPL ) which is not considered a merchant phosphate. The other reason is that PAPRs appear to be more an attractive alternative fertilizer of TSP. Indeed, the amount of phosphoric acid required to manufacture this fertilizer is considerably low.

\section{MATERIAL AND METHODS}

Phosphate samples mentioned in Table 1 was provided by the Algerian phosphate company (FERPHOS). All samples was analyzed by appropriate analytical methods such as spectrophotometry for $\mathrm{SiO}_{2}, \mathrm{Fe}_{2} \mathrm{O}_{3}, \mathrm{Cl}^{-}$and $\mathrm{F}^{-}$, complexometric titration with a standard solution of EDTA for $\mathrm{CaO}, \mathrm{MgO}$ and $\mathrm{Al}_{2} \mathrm{O}_{3}$ and finally the flame spectrophotometry for sodium and potassium. The apparatus TECHNICON AUTO ANALYZER standardized NS ${ }^{24}$. NF U42-201 was used for spectrophotometric analysis of $\mathrm{P}_{2} \mathrm{O}_{5}$ (molybdovanadate method) ${ }^{\mathbf{2 5}}$.

The following sieves were used to collect phosphate samples: 170 mesh, 80 mesh, 70 mesh and 35 mesh. The particles passed through these respective sieves are:

Table 1. Chemical composition of Djebel Onk phosphate $53.75 \%$ BPL

\begin{tabular}{|l|c|}
\hline Chemical compound & Content [\% mass] \\
\hline $\mathrm{P}_{2} \mathrm{O}_{5}$ & 24.60 \\
\hline $\mathrm{CO}_{2}$ & 11.15 \\
\hline $\mathrm{CaO}$ & 45.18 \\
\hline $\mathrm{MgO}$ & 4.20 \\
\hline $\mathrm{Na}_{2} \mathrm{O}$ & 1.20 \\
\hline $\mathrm{K}_{2} \mathrm{O}$ & 0.10 \\
\hline $\mathrm{Fe}_{2} \mathrm{O}_{3}$ & 0.38 \\
\hline $\mathrm{Al}_{2} \mathrm{O}_{3}$ & 0.20 \\
\hline $\mathrm{SO}_{3}$ & 2.50 \\
\hline $\mathrm{SiO}_{2}$ & 3.00 \\
\hline $\mathrm{F}^{-}$ & 3.20 \\
\hline $\mathrm{Cl}^{-}$ & $350[\mathrm{ppm}]$ \\
\hline Organic matters (Organic C) & 3.80 \\
\hline
\end{tabular}

$88 \mu \mathrm{m}, 177 \mu \mathrm{m}, 210 \mu \mathrm{m}$ and $500 \mu \mathrm{m}$. Note that the $\mu \mathrm{m}$ values designate the average diameter of phosphate grains expressed in micrometer. The test samples are dried in an electric oven at $110^{\circ} \mathrm{C}$, cooled to room temperature and stored in desiccators.

All reactions were carried out in a $500 \mathrm{ml}$ cylinder glass reactor (inner diameter of $7 \mathrm{~cm}$ ) at atmospheric pressure. For each test, $100 \mathrm{~g}$ of phosphate sample was mixed, in an agitated reactor, with phosphoric acid. Stirring is performed by means of a mechanical agitator, at $200 \mathrm{rpm}$, in order to accelerate the transfer of matter between the different phases. At the end of each experiment, the reactor is placed rapidly in a bath of ice, to stop the reaction, and all the reactor contents were then filtered off using a Buchner filter. The filtration is performed by a vacuum pump.

\section{Determination of the $\mathrm{P}_{\mathbf{2}} \mathrm{O}_{\mathbf{5}}$ recovery}

A $5 \mathrm{ml}$ aliquot part of the filtrate is transferred to a $50 \mathrm{ml}$ volumetric flask. After filling up to the mark with water, the $\mathrm{P}_{2} \mathrm{O}_{5}$ amount in solution is determined spectrometric ally by UV/Vis spectrophotometer PerkinElmer using molybdovanadate spectrophotometric method. The $\mathrm{P}_{2} \mathrm{O}_{5}$ recovery, expressed in \% of weight was calculated by applying the formula:

$\% \mathrm{P}_{2} \mathrm{O}_{5}$ recovery $=\frac{\left(\mathrm{m}_{0}-\mathrm{m}\right) \cdot 100}{\mathrm{~m}_{0}}$

where:

$-m_{0}$ is the initially introduced mass of $\mathrm{P}_{2} \mathrm{O}_{5}$ equals $24.60 \mathrm{~g}$ (the equivalent of $100 \mathrm{~g}$ of phosphate sample),

$-m$ is the total analyzed $\mathrm{P}_{2} \mathrm{O}_{5}$ in the filtrate after a time $\mathrm{t}$ of reaction.

\section{Determination of water-soluble $\mathbf{P}_{\mathbf{2}} \mathbf{O}_{\mathbf{5}}$}

The partially acidulated phosphate obtained previously at different concentrations of $\mathrm{H}_{3} \mathrm{PO}_{4}$ is brought into contact with distilled water for periods of 2 to 30 days to measure the water-soluble $\mathrm{P}_{2} \mathrm{O}_{5}$. This experience is described as follows:

The sample of $1 \mathrm{~g}$ of the partially acidulated phosphate is contacted with $400 \mathrm{ml}$ of distilled water in a closed bottle. After a defined period, the bottle is agitated for 15 minutes. To the resulting suspension, we add distilled water to volume $1000 \mathrm{ml}$. We stir it again to mix and we filter on the filter paper. Then, we take $5 \mathrm{ml}$ of the filtrate and we determine the amount of $\mathrm{P}_{2} \mathrm{O}_{5}$ by the spectrophotometric method.

\section{RESULTS AND DISCUSSION}

A number of experiments were carried out in order to follow, in terms of $\mathrm{P}_{2} \mathrm{O}_{5}$ recovery, the effect of some parameters on the dissolution of the phosphate rocks by phosphoric acid. These parameters are : reaction time, concentration of phosphoric acid and particle size of phosphate rocks.

\section{Effect of reaction time effect}

The results presented in Tables 2, 3, 4 and 5 indicate that the reaction is faster during first ten minutes but in the interval 10-30 minutes, the $\mathrm{P}_{2} \mathrm{O}_{5}$ recovery increase almost proportionally as a function of time. However, regardless the acid concentration and the phosphate 
particle size, the recovery $\mathrm{P}_{2} \mathrm{O}_{5}$ increases very slowly during the interval 30 to 40 minutes. This phenomenon is probably due to the diffusion of $\mathrm{Ca}^{2+}$ from the solid surface through the solution boundary layer a result of which, the acid concentration at the liquid-solid interface decreases the rate of dissolution of calcareous material from the apatite. Almost the same observation was made by Ashraf et al. ${ }^{26}$

\section{Effect of the concentration of $\mathrm{H}_{3} \mathrm{PO}_{4}$}

The effect of phosphoric acid concentration ranging from 10 to 40 wt.\% on the dissolution of phosphate rock was studied at room temperature and at $88-500 \mu \mathrm{m}$ particle size fraction. The results presented in Tables 2 , 3,4 and 5 indicate that the $\mathrm{P}_{2} \mathrm{O}_{5}$ recovery is proportional to the phosphoric acid concentration. Indeed, more the concentration of the acid as $\mathrm{P}_{2} \mathrm{O}_{5}$ is low, more the $\mathrm{P}_{2} \mathrm{O}_{5}$ recovery is slower and more the maximum of dissolution is quickly reaches. When the phosphoric acid concentration increases from 10 to $40 \mathrm{wt} . \%$ the $\mathrm{P}_{2} \mathrm{O}_{5}$ recovery increased from about 14.51 to $11.84 \%$. However, the top $\mathrm{P}_{2} \mathrm{O}_{5}$ recovery $(34.80 \%)$ is obtained at higher acidulation levels $(40 \mathrm{wt} \%)$.

\section{Effect of particle size of phosphate}

The effect of phosphate rock particles size on the $\mathrm{P}_{2} \mathrm{O}_{5}$ recovery was studied for the different fractions: 88 $\mu \mathrm{m}, 177 \mu \mathrm{m}, 210 \mu \mathrm{m}, 250 \mu \mathrm{m}$ and $500 \mu \mathrm{m}$. Experiments are conducted under conditions giving the best $\mathrm{P}_{2} \mathrm{O}_{5}$ recovery, namely :

- Stirring speed: $200 \mathrm{rpm}$;

- Concentration of $\mathrm{H}_{3} \mathrm{PO}_{4}$ : 40 wt.\%;

- Reaction time: 50 minutes.

Figure 1 shows that the $\mathrm{P}_{2} \mathrm{O}_{5}$ recovery decreases when using the phosphates with larger particles. This decrease is less significant with phosphates having $210 \mu \mathrm{m}$ and more but phosphates having particle size lower than 210 $\mu \mathrm{m}$ give the best $\mathrm{P}_{2} \mathrm{O}_{5}$ recovery. Indeed, the maximum $\mathrm{P}_{2} \mathrm{O}_{5}$ recovery $(34.8 \%)$ is obtained with phosphate passed

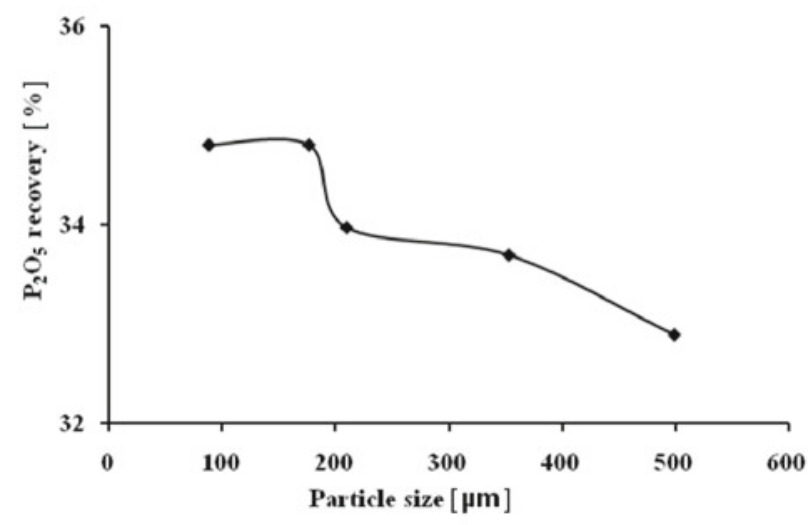

Figure 1. Effect of phosphate particle size on $\mathrm{P}_{2} \mathrm{O}_{5}$ recovery

Table 2. Effect of reaction time and phosphoric acid concentration on $\mathrm{P}_{2} \mathrm{O}_{5}$ recovery from phosphate particle size $88 \mu \mathrm{m}$

\begin{tabular}{|l|c|c|c|c|}
\hline \multicolumn{5}{|c|}{$\mathrm{P}_{2} \mathrm{O}_{5}$ recovery [\%] } \\
\hline Time [min] & $\begin{array}{c}\text { Concentration of } \\
\mathrm{H}_{3} \mathrm{PO}_{4}=10 \text { wt. } \%\end{array}$ & $\begin{array}{c}\text { Concentration of } \\
\mathrm{H}_{3} \mathrm{PO}_{4}=20 \text { wt. } \%\end{array}$ & $\begin{array}{c}\mathrm{C}_{4} \\
\mathrm{H}_{3} \mathrm{PO}_{4}=30 \text { wt. } \%\end{array}$ & $\begin{array}{c}\text { Concentration of } \\
\mathrm{H}_{3} \mathrm{PO}_{4}=40 \text { wt. } \%\end{array}$ \\
\hline 10 & 18.10 & 25.18 & 30.27 & 32.61 \\
\hline 20 & 21.24 & 26.13 & 32.34 & 34.02 \\
\hline 30 & 22.62 & 29.42 & 33.45 & 34.51 \\
\hline 40 & 22.90 & 29.64 & 34.10 & 34.80 \\
\hline 50 & 22.94 & 29.66 & 34.08 & 34.78
\end{tabular}

Table 3. Effect of reaction time and phosphoric acid concentration on $\mathrm{P}_{2} \mathrm{O}_{5}$ recovery from phosphate particle size $177 \mu \mathrm{m}$

\begin{tabular}{|l|c|c|c|c|}
\hline \multicolumn{5}{|c|}{$\mathrm{P}_{2} \mathrm{O}_{5}$ recovery [\%] } \\
\hline Time [min] & $\begin{array}{c}\text { Concentration of } \\
\mathrm{H}_{3} \mathrm{PO}_{4}=10 \text { wt. } \%\end{array}$ & $\begin{array}{c}\text { Concentration of } \\
\mathrm{H}_{3} \mathrm{PO}_{4}=20 \text { wt. } \%\end{array}$ & $\begin{array}{c}\text { Concentration of } \\
\mathrm{H}_{3} \mathrm{PO}_{4}=30 \text { wt.\% }\end{array}$ & $\begin{array}{c}\text { Concentration of } \\
\mathrm{H}_{3} \mathrm{PO}_{4}=40 \text { wt. \% }\end{array}$ \\
\hline 10 & 18.03 & 25.12 & 30.11 & 32.54 \\
\hline 20 & 21.18 & 26.04 & 32.22 & 33.97 \\
\hline 30 & 22.44 & 29.14 & 33.61 & 34.18 \\
\hline 40 & 22.87 & 29.52 & 34.00 & 34.76 \\
\hline 50 & 22.90 & 29.60 & 34.02 & 34.80 \\
\hline
\end{tabular}

Table 4. Effect of reaction time and phosphoric acid concentration on $\mathrm{P}_{2} \mathrm{O}_{5}$ recovery from phosphate particle size $210 \mu \mathrm{m}$

\begin{tabular}{|l|c|c|c|c|}
\hline \multicolumn{5}{|c|}{$\mathrm{P}_{2} \mathrm{O}_{5}$ recovery [\%] } \\
\hline Time [min] & $\begin{array}{c}\text { Concentration of } \\
\mathrm{H}_{3} \mathrm{PO}_{4}=10 \text { wt. } \%\end{array}$ & $\begin{array}{c}\text { Concentration of } \\
\mathrm{H}_{3} \mathrm{PO}_{4}=20 \text { wt. } \%\end{array}$ & $\begin{array}{c}\text { Concentration of } \\
\mathrm{H}_{3} \mathrm{PO}_{4}=30 \text { wt. } \%\end{array}$ & $\begin{array}{c}\text { Concentration of } \\
\mathrm{H}_{3} \mathrm{PO}_{4}=40 \text { wt. } \%\end{array}$ \\
\hline 10 & 17.56 & 24.92 & 29.10 & 30.01 \\
\hline 20 & 20.02 & 25.33 & 31.78 & 33.11 \\
\hline 30 & 21.65 & 28.04 & 32.89 & 33.65 \\
\hline 40 & 21.93 & 28.52 & 32.94 & 33.98 \\
\hline 50 & 21.92 & 28.63 & 32.97 & 33.98 \\
\hline
\end{tabular}

Table 5. Effect of reaction time and phosphoric acid concentration on $\mathrm{P}_{2} \mathrm{O}_{5}$ recovery from phosphate particle size $500 \mu \mathrm{m}$

\begin{tabular}{|l|c|c|c|c|}
\hline \multicolumn{5}{|c|}{$\mathrm{P}_{2} \mathrm{O}_{5}$ recovery [\%] } \\
\hline Time [min] & $\begin{array}{c}\text { Concentration of } \\
\mathrm{H}_{3} \mathrm{PO}_{4}=10 \text { wt. } \%\end{array}$ & $\begin{array}{c}\text { Concentration of } \\
\mathrm{H}_{3} \mathrm{PO}_{4}=20 \text { wt. } \%\end{array}$ & $\begin{array}{c}\text { Concentration of } \\
\mathrm{H}_{3} \mathrm{PO}_{4}=30 \text { wt. \% }\end{array}$ & $\begin{array}{c}\text { Concentration of } \\
\mathrm{H}_{3} \mathrm{PO}_{4}=40 \text { wt. } \%\end{array}$ \\
\hline 10 & 15.23 & 21.44 & 26.98 & 28.57 \\
\hline 20 & 16,58 & 22.67 & 29.32 & 29.82 \\
\hline 30 & 18.94 & 22.77 & 30.19 & 32.15 \\
\hline 40 & 20.02 & 23.54 & 31.92 & 32.71 \\
\hline 50 & 20.12 & 23.70 & 32.16 & 32.90 \\
\hline
\end{tabular}


through the sieve 170 mesh $(88 \mu \mathrm{m})$ and the sieve 80 mesh $(177 \mu \mathrm{m})$. This is consistent with the work of Lassis et al. ${ }^{22}$. Generally the $\mathrm{P}_{2} \mathrm{O}_{5}$ recovery is inversely proportional to the phosphate particle size which may be due to the increase of the specific surface area. These results corroborate with the work of Lefires et al. ${ }^{27}$ which have concluded that the specific surface area and the isotherm adsorption/desorption of the solids are affected by the acid leaching time.

\section{Water-soluble $\mathbf{P}_{\mathbf{2}} \mathbf{O}_{5}$}

The curves in Figures 2, 3 and 4 were obtained by acidulation of phosphates of varying sizes with phosphoric acid concentration of $30 \mathrm{wt} \%$ and $40 \mathrm{wt} . \%$ because these acids gives better $\mathrm{P}_{2} \mathrm{O}_{5}$ recovery (see Tables 2, 3, 4 and 5). We note that for all the phosphates PAPRs obtained with acid $40 \%$ has approximately $0.8 \%$ water soluble $\mathrm{P}_{2} \mathrm{O}_{5}$ more than PAPRs obtained with an acid of $30 \%$. When the PAPRs is left in contact with distilled water for the following periods: $2 ; 4 ; 8 ; 16 ; 20$ and 30 days, we observed that the water-soluble $\mathrm{P}_{2} \mathrm{O}_{5}$ increased progressively during the first 16 days. After the 20th day, the dependence of the residence time and water-soluble $\mathrm{P}_{2} \mathrm{O}_{5}$ is almost constant. Comparing Figures 2, 3 and 4 we observe that the phosphate with a $88 \mu \mathrm{m}$ particle size used for the preparation of PAPRs gives the best percentage of water soluble $\mathrm{P}_{2} \mathrm{O}_{5}(15.2 \%)$.

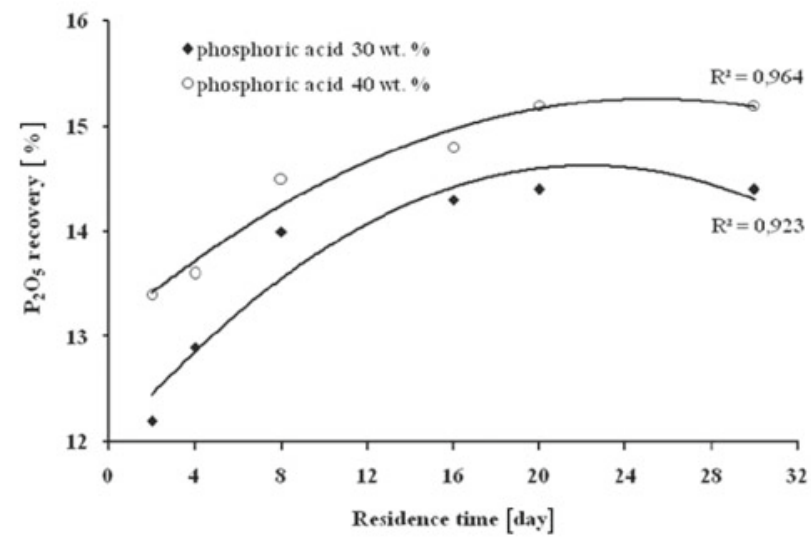

Figure 2. Water-soluble $\mathrm{P}_{2} \mathrm{O}_{5}$ as function of residence time for the phosphate $88 \mu \mathrm{m}$

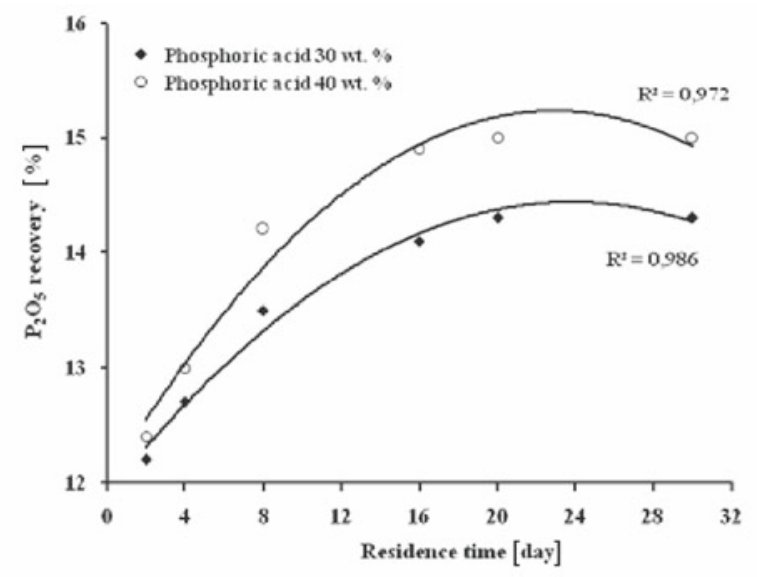

Figure 3. Water-soluble $\mathrm{P}_{2} \mathrm{O}_{5}$ as function of residence time for the phosphate $210 \mu \mathrm{m}$

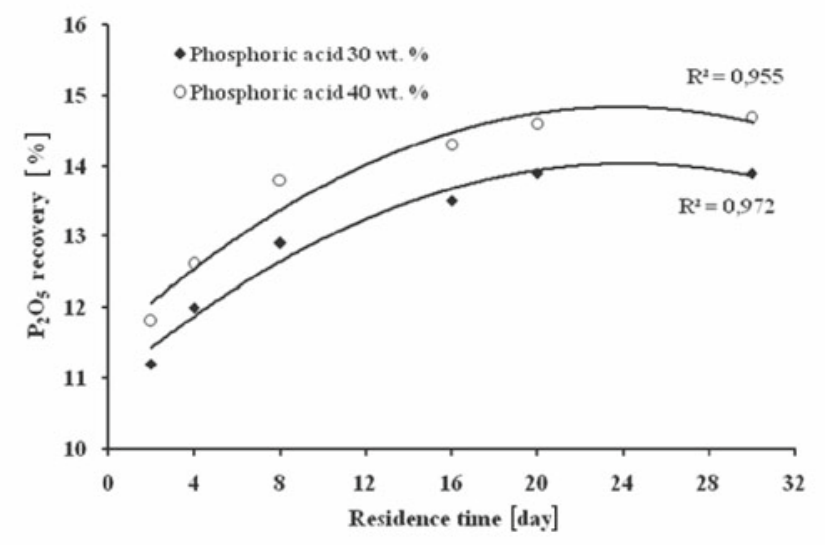

Figure 4. Water-soluble $\mathrm{P}_{2} \mathrm{O}_{5}$ as function of residence time for the phosphate $500 \mu \mathrm{m}$

This value is better than that obtained by the decomposition by sulfuric acid of a high-grade phosphate $(65.55 \% \text { BPL })^{\mathbf{2 0}}$.

\section{CONCLUSIONS}

This work showed that the production of PAPRs may be feasible with intermediate-grade phosphate of Djebel Onk and modest levels of acidulation of phosphoric acid. Since this study showed that concentrated $\mathrm{H}_{3} \mathrm{PO}_{4}$ to 30 or $40 \mathrm{wt} \%$ gives PAPRs with good water solubility, it is therefore possible to extract the phosphoric acid before the step of concentration (Dihydrate Process) ${ }^{\mathbf{2 8}}$ from the phosphoric acid plant to produce this fertilizer. On these conditions, the PAPRs obtained can substitute the SSP fertilizers because they are economically profitable and probably less harmful to the environment. (to be confirmed by other studies); this is especially true because some heavy metals contained in phosphates rock will dissolve at high concentrations of acid.

\section{ACKNOWLEDGEMENT}

The authors gratefully acknowledge the financial support of Directorate General of Scientific Research and Technological Development (Algeria). Phosphate Company FERPHOS is gratefully acknowledged for providing a representative sample of the phosphate deposit and its supply of data necessary for this work.

\section{LITERATURE CITED}

1. Ashraf, M., Iqbal-Zafar, Z. \& Ansari, T. ( 2005). Selective leaching kinetics and upgrading of low-grade calcareous phosphate rock in succinic acid. Hydrometallurgy 80(4), 286-292. DOI: 10.1016/j.hydromet.2005.09.001.

2. Skut, J., Hoffmann, K. \& Hoffmann, J. (2012). Temperature and moisture influence on the curing process of PAPR-type fertilizer products. Pol. J. Chem. Tech.14 (3), 77-82. DOI: 10.2478/v10026-012-0088-z.

3. IAEA. (2004). Occupational radiation protection in the mining and processing of raw materials. IAEA Safety Standards Series No. RS-G-1.6, IAEA. Vienna.

4. Watti, A., Alnjjar, M. \& Hammal, A. (2011). Improving the specifications of Syrian raw phosphate by thermal treatment. Arab J. Chem. DOI: 10.1016/j. arabjc.2011.07.009. 
5. Sengul, H., Ozer, A.K. \& Gulaboglu, M.S. (2006). Benefication of Mardin Mazidagi calcareous phosphate rock using dilute acetic acid solutions. Chem. Eng. J. 122 (3), 135-140. DOI: 10.1016/j.cej.2006.06.005.

6. Mahdi, G., Mehdi, I. \& Mohammad, N. (2010). A review of the beneficiation of calcareous phosphate ores using organic acid leaching. Hydrometallurgy 103(1-4), 96-107. DOI: 10.1016/j.hydromet.2010.03.002.

7. McSweeney, G. \& Charleston, A.G. (1985). Partially acidulated phosphate rocks-reactions with water. Nutr. Cycl. Agroecosys. 8(1), 75-83. DOI: 10.1007/BF01048908. 8. Schultz, J.J. (1986). Sulfuric acid-based partially acidulated phosphate rock: Its production, cost, and use. Tech. Bull.IFDC-T-31. Muscle Shoals, USA, IFDC. 9. Bolan, N.S., Hedley, M.J. \& Loganathan, P. (1993). Preparation, forms and properties of controlled-release phosphate fertilizers. Nutr. Cycl. Agroecosys 35(1), 13-24. DOI: $10.1007 / \mathrm{BF} 00750216$.

10. Hammond, L.L., Chien, S.H. \& Mokwunye, A.U. (1986). Agronomic value of unacidulated and partially acidulated phosphate rocks indigenous to the tropics. $A d v$. Agron. 40, 89-140. DOI: 10.1016/S0065-2113(08)60281-3. 11. Braithwaite, A.C. \& Rogers, D.A. (1987). Partially acidulated phosphate rocks made from phosphoric acid using direct acidulation-granulation techniques. Fert Res. 12(1), 85-98. DOI: 10.1007/BF01049422.

12. Ghani, A. \& Rajan, S.S.S. (1997). Differential availability of partially sulphuric and phosphoric acidulated phosphate rocks I. Plant Response. Nutr. Cycl. Agroecosys. 47(3), 251-259. DOI: 10.1007/BF01986280.

13. Marwaha, B.C. \& Rajan, S.S.S. (1993). Use of partially acidulated phosphate rocks as phosphate fertilizers. Nutr. Cycl. Agroecosys. 35(1), 47-59. DOI: 10.1007/BF00750219. 14. Iretskaya, S.N., Chien, S.H. \& Menon, R.G. (1998). Effect of acidulation of high cadmium containing phosphate rocks on cadmium uptake by upland rice. Plant Soil 201(2), 183-188. DOI: 10.1023/A:1004323715299.

15. McLaya, C.D.A., Rajana, S.S.S. \& Liua, Q. (2000). Agronomic effectiveness of partially acidulated phosphate rock fertilizers in an allophanic soil at nearneutral pH. Soil Sci. Plant Anal. 31(3-4), 423-435. DOI: 10.1080/00103620009370447.

16. Ghosal, P.K. \& Chakraborty, T. (2012). Comparative solubility study of four phosphatic fertilizers in different solvents and the effect of soil. Res. Environ. 2(4), 75-179. DOI: $10.5923 /$ j.re.20120204.07.

17. Schultz, J.J. (1986). Sulfuric acid-based partially acidulated phosphate rock: Its production, cost, and use. Tech. Bull.IFDC-T-31. Muscle Shoals, USA, IFDC. 18. Bolan, N.S. Hedley, M.J., Syers, J.K. \& Tillman, R.W. (1987). Single superphosphate-reactive phosphate rock mixtures.Factors affecting chemical composition. Fert. Res. 13(3), 223-239. DOI: 10.1007/BF01066446.

19. Hedley, M.J., Bolan, N.A. \& Braithwaite, A.C. (1988). Single superphosphate-reactive phosphate rock mixtures. The effect of phosphate rock type and denning time on the amounts of acidulated and extractable phosphate. Fert. Res. 16(2), 179-194. DOI: 10.1007/BF01049773.

20. Mizane, A. \& Rehamnia, R. (2012). Study of some parameters to obtain the $\mathrm{P}_{2} \mathrm{O}_{5}$ water- Soluble from partially acidulated phosphate rocks (PAPRs) by sulfuric acid. Phosph. Res. Bull. 27, 27-18. DOI: doi.org/10.3363/prb.
21. Bezzi, N., Aiffa, T., Hamoudi, S. \& Merabet, D. (2012). Trace elements of Kef Es Sennoun natural Phosphate (Djebel Onk, Algeria) and how they affect the various mineralurgic modes of treatment. Proced. Engine. 42, 1915-1927.

22. Lassis, M., Mizane, A., Dadda, N. \& Rehamnia, R. (2015). Dissolution of Djebel Onk phosphate ore using sulfuric acid. Environ. Nanotech., Monit. \& Manag. 4, 12-16. DOI: doi.org/10.1016/j.enmm.2015.03.002.

23. United States Geological Survey (2011). Mineral Commodity Summaries, January 2011. http://minerals. usgs.gov/minerals/pubs/commodity/phosphate_rock/mcs2011-phosp.pdf

24. French standards NF U42-201. Phosphates minéraux naturels et engrais Dosage spectrophotométrique de l'anhydride phosphorique (méthode vanadomolybdique). 25. Basson, W.D., Van Staden, J.F. \& Cattin, P.M. (1981). Determination of phosphorus $\left(\mathrm{P}_{2} \mathrm{O}_{5}\right)$ as molybdovanadophosphoric acid in phosphate rock with a flow-injection procedure. An. Bioan. Chem J. (307), 373-377. DOI: 10.1007/BF00480116.

26. Ashraf, M., Zafar, I., Ansari, T.M. \& Fiaz, A. (2005). Selective Leaching Kinetics of Calcareous Phosphate Rock in Phosphoric Acid. J. Appl. Sci. (5), 1722-1727. DOI: $10.3923 /$ jas.2005.1722.1727.

27. Lefires, H., Medini, H., Megriche, A. \& Mgaidi, A. (2014). Dissolution of Calcareous Phosphate Rock from Gafsa (Tunisia) Using Dilute Phosphoric Acid Solution. Inter. J. Nonfer. Metal. (3), 1-7. DOI: doi.org/10.4236/ ijnm.2014.31001.

28. European Fertilizer Manufacturers' Association. (2000). Production of phosphoric acid. Booklet No. 4 of 8. Brussels, Belgium. http://www.productstewardship.eu/ fileadmin/user_upload/user_upload_prodstew/documents/ Booklet_nr_4_Production_of_Phosphoric_Acid.pdf 